\title{
Climatic Fluctuations, Drought, and Flow in the Colorado River Basin
}

\section{Introduction}

Climatic fluctuations have profound effects on water resources in the western United States (fig. 1). In the arid and semiarid Southwest, climatic fluctuations affect many hydrologic characteristics of watersheds, including the quantity of base flow, the occurrence of large floods, and the timing of snowmelt runoff (Cayan and others, 1999; Stewart and others, 2004). Since the start of a persistent drought around the year 2000, inflows to Lake Powell on the Colorado River have been below average, leading to drawdown of Lake Mead and Lake Powell (fig. 2 ), the primary means of storage on the river. Although the factors that caused and have sustained this drought have not been positively identified, it is possible to describe the broader climatic context within which it is occurring. This fact sheet provides a perspective on the current drought occurring in parts of the western United States, particularly in the Colorado River basin.

\section{Sources of Moisture to the Colorado River Basin}

Precipitation on the Colorado Plateau is biseasonal, having both winter and summer regimes (Hereford and others, 2002). In the headwaters, precipitation generally is evenly distributed across the four seasons, accumulating mostly in snowpacks. Moisture comes from several sources (fig. 1). Winter and spring frontal systems originating in the North Pacific Ocean, provide the largest and most important source of moisture. These largescale systems tend to carry moisture at higher levels in the atmosphere, with orographic effects of the mountainous West causing an increase in

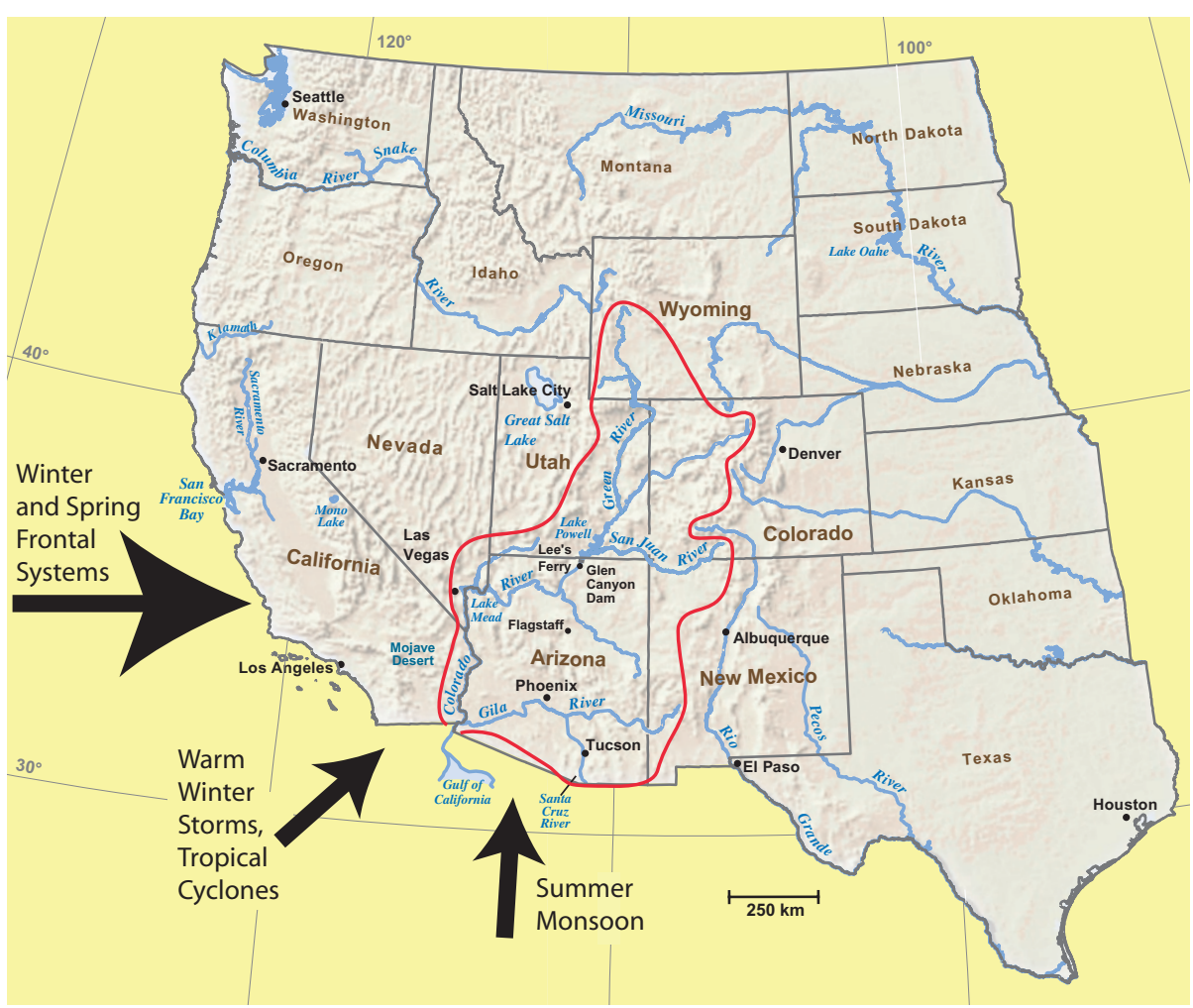

Figure 1. Moisture sources to the Colorado River basin.

precipitation with elevation. Cold frontal systems produce substantial amounts of snow above about 5,000 feet and rainfall at lower elevations in the Rocky, Uinta, and Wind River Mountains, which constitute the headwaters of the Colorado River and its principal tributary, the Green River. These storms build snowpacks that melt in the late spring, providing runoff to the Colorado River. Warm winter storms, which may tap moisture from the tropical Pacific Ocean, may produce rainfall on snowpacks, resulting in high runoff and floods on major rivers. The frequency and moisture content of frontal systems are strongly affected by atmospheric circulation patterns and sea-surface temperature (SST) of the tropical and North Pacific Oceans.

Moisture delivered to the Colorado River basin during summer typically is a mixture of moist air from the Gulf of Mexico, the Gulf of California, and the eastern Pacific Ocean. Known as the "North American monsoon," this moisture arrives at low levels in the atmosphere in July and August. Under the influence of strong heating and upslope flow, the moist air helps spawn thunderstorms that generally deliver high-intensity rainfall to elevations below about 7,000 feet and lower-intensity rainfall at higher elevations. Thunderstorms tend to be of small spatial extent, and although they may cause severe flash flooding locally, few floods are generated on the larger rivers in the region.

Warm-core systems (tropical depressions, tropical storms, and hurricanes) form in the eastern North Pacific Ocean off the west coast of Mexico. These storms rarely make direct landfall on the continental United States, tending 

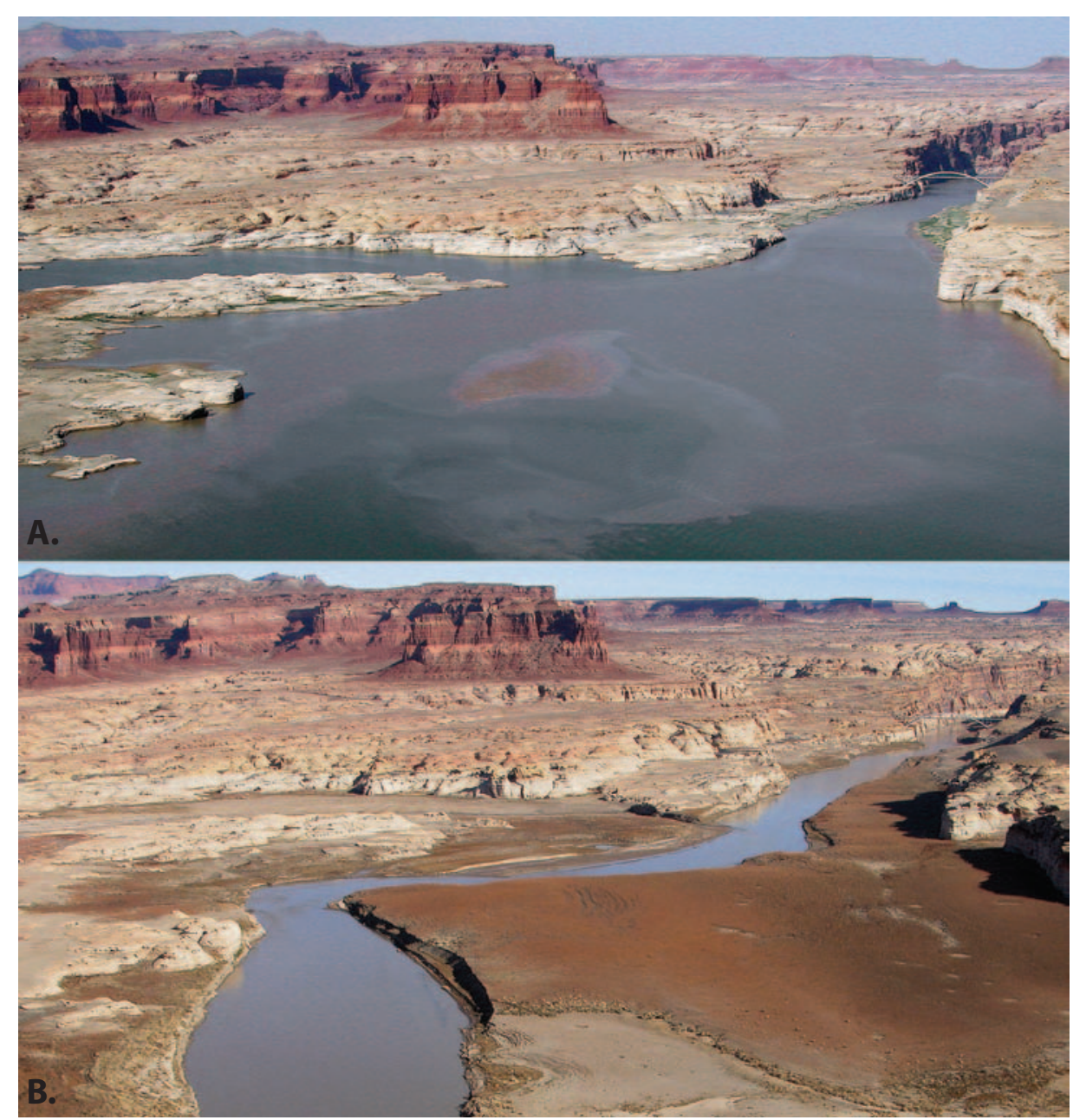

Figure 2. Replicate photographs of Lake Powell at the confluence with the Dirty Devil River (entering from left). A. June 29, 2002. B. December 23, 2003. (Photographs by John C. Dohrenwend)

instead to dissipate over the ocean. Residual moisture from such storms, however, which can be considerable, is occasionally transported inland into the southwestern United States. This residual moisture, as well as that from tropical systems that occasionally transit the Southwest, produces precipitation that can generate large floods in the southern half of the Colorado River basin.

\section{Oceans, Climate, and Drought}

During the past 30 years, our understanding of the climatic importance of the oceans, particularly ocean temperature, has steadily improved. Initial research focused on the distant effects of the recurrent warming of the equatorial Pacific Ocean referred to as El Niño, which South American fishermen have long known to have an adverse affect on the coastal fisheries in Peru. El Niño is the warm phase of the sea-surface temperature component of a coupled and westward from the coast into the eastern and central Pacific, producing La Niña. Thus, El Niño and La Niña are, respectively, the warm and cold phases of the coupled ENSO system.

ENSO events typically last from 6 to 18 months and, therefore, are the single most important factor affecting interannual climatic variability on a global scale (Diaz and Kiladis, 1992). ENSO has been linked to the occurrence of flooding in the lower Colorado River basin (Webb and Betancourt, 1992) and to both floods and droughts across the western United States (Cayan and others, 1999). Warm winter storms have been enhanced during El Niño, causing above-average runoff and floods in the Southwest, such as during 1982-1983. Not all El Niño events, however, lead to increased runoff in the Southwest. For example, during the 2002-2003 warm episode, runoff was below average in the Colorado River basin. Similarly, La Niña, is frequently, though not always, associated with belowaverage flow in the Colorado River. As a result, although ENSO exerts a strong influence in modulating wet versus dry conditions in many parts of the United States, the effect is not always the same in any given region. Some condition other than ENSO must also be influencing weather and climate patterns affecting the Colorado River.

In the mid-1990s, scientists identified another ocean temperature pattern, this one occurring in the extratropical Pacific Ocean north of $20^{\circ} \mathrm{N}$ (Mantua and Hare, 2002), which was named the Pacific Decadal Oscillation (PDO). The PDO varies or oscillates on a decadal scale of 30-50 years for the total cycle; that is, much of the North Pacific Ocean will be predominantly though not uniformly warm (or cool) for periods of about 15 to 25 years. During the $20^{\text {th }}$ century, the PDO exhibited several phases, being warm along coastal southeastern Alaska from 1923-1943 and again from 1976-1998, and cool from 1944-1975. Since 1999, the PDO has exhibited higher-frequency fluctuations, varying from cool (1999-2001) to warm (2002-2004). Currently, the causes of the varia- 


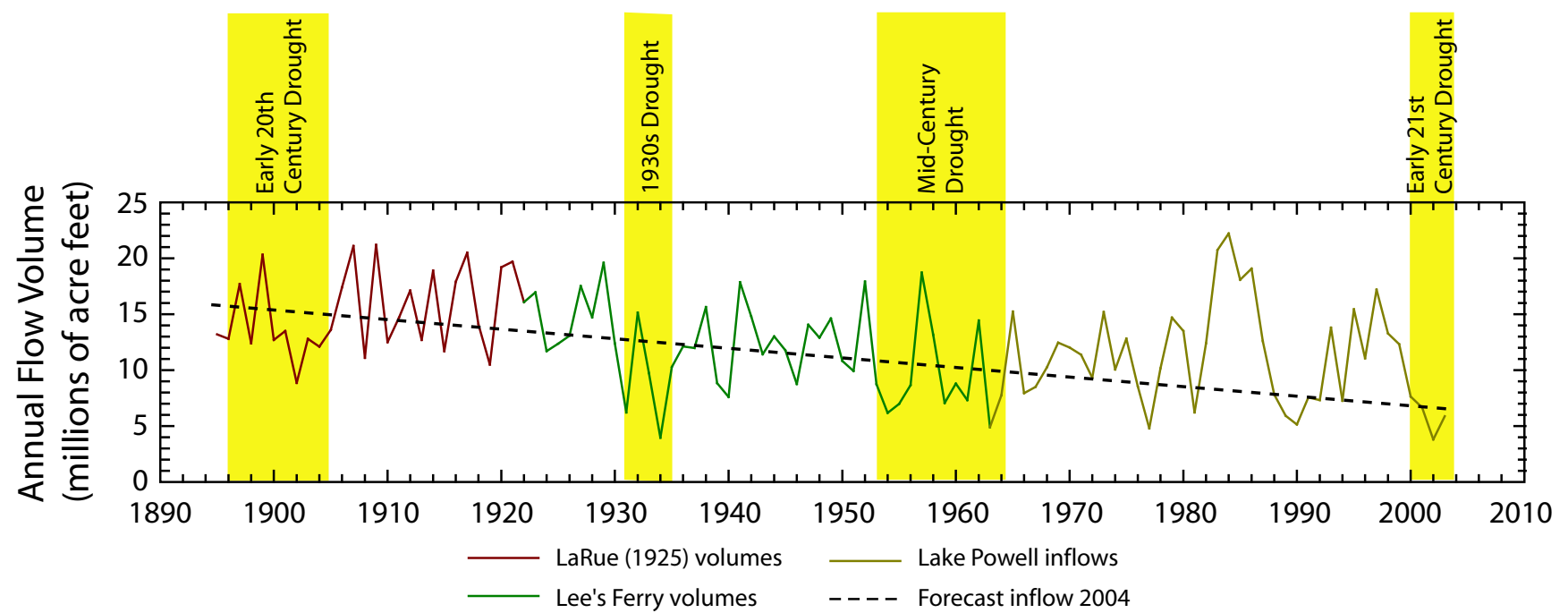

Figure 3. Time-series plot of the annual flow volume (in millions of acre-feet) for the Colorado River at Lee's Ferry. Dashed line is the linear trend for the period. Vertical bars and shading delineate drought periods as defined using the Palmer Drought Severity Index for the climate divisions encompassing the upper Colorado River basin.

tions in the PDO are unknown and its potential predictability is uncertain. Recent research indicates that the PDO phase may be associated with decadal-length periods of above- and below-average precipitation and streamflow in the Colorado River basin (Hidalgo, in press) but, as with ENSO, such associations are not always consistent.

Most recently, researchers discovered that sea-surface temperatures in the North Atlantic Ocean exhibit a similar pattern of long-term persistence. The pattern, identified as the Atlantic Multidecadal Oscillation (AMO), refers to multidecadal warm and cool periods in ocean temperature each lasting 20 to 35 years (Kerr, 2000; Enfield and others, 2001). Atlantic "cool" phases were observed from 1902-1925 and from 1964-1994, whereas a "warm" phase occurred almost continuously from 1926-1963. The Atlantic again entered a warm phase in 1996 and has remained so since. Such long periods of consistent temperature indicate that the AMO is much more persistent than the PDO. In addition, preliminary research indicates that these long periods of persistent Atlantic temperatures may be associated with the delivery of moisture to the United States. For example, Schubert and others (2004) found that during warm Atlantic phases, the easterly atmospheric flow from the Atlantic and Gulf of Mexico is shifted farther southward, and moisture delivery to the contermi- nous United States is diminished in certain seasons. In addition, several investigators have reported that warm Atlantic Ocean conditions appear to coincide with an increase in drought frequency over parts of the United States (Gray and others, 2003; 2004; McCabe and others, 2004).

As our knowledge about the influence of the oceans on climate increases, so too does our awareness of the enormous complexity of the ocean-atmosphere system. Over time, scientists have learned that no single feature of the system (e.g., ENSO, PDO, AMO) explains all of the variations that occur in weather and climate. It is increasingly evident that the various features are interrelated in a complicated fashion. Their effect on climate depends on the direction and magnitude of their variations and possibly other factors that may not yet have been identified.

\section{Flow in the Colorado River}

Flow in the Colorado River varied significantly during the $20^{\text {th }}$ century. Lee's Ferry (fig. 1) is, by convention, taken to be the location that separates the upper-basin States of Wyoming, Colorado, Utah, and New Mexico from the lower-basin States of Nevada, Arizona, and California as documented in the Colorado River Compact of 1922. Calendaryear flow volumes (fig. 3) were combined from three data sets that were measured or estimated using different techniques. Consumptive water uses in the basin upstream of the stream-gaging station at Lee's Ferry are not included in these data. The flow values represent the amount of water in the river at Lee's Ferry. Thus, variability in the flow values is due both to climatic fluctuations as well as to changes in consumptive water use upstream from the Lee's Ferry station.

The primary data for the Colorado River at Lee's Ferry were estimated or collected from 1895 through 1962, one year before flow regulation began at Glen Canyon Dam. From 1895 through 1922, annual flow volumes at Lee's Ferry were estimated by LaRue (1925, p. 108), and are distinguished from volumes measured at the Lee's Ferry streamgaging station from 1923 through 1962.

From 1963 through 2003, flow at Lee's Ferry is assumed to be approximated as the sum of flow volumes of the principal rivers flowing into Lake Powell. From 1950 through 1962, comparison of these inflows with the flow measured at Lee's Ferry indicated that inflow was, on average, 290,000 acre-feet per year less than the measured flow (about 2 percent of the annual flow volume). Although this is well within the measurement error of stream-gaging stations, to account for this bias, the inflows to Lake Powell were adjusted using a regression equation calibrated on earlier years for the period 1963-2003. The time series of flow volumes (fig. 3 ) shows that 
the average annual volume was 12.4 million acre-feet (MAF) from 1895 through 2003. This volume is less than the more commonly quoted annual volume of 15.0 MAF because these analyses do not include water that is consumptively used in the upper basin States. The trend in annual flow volume, which decreased by about 0.5 MAF per decade from 1895 through 2003 (fig. 3), is due, in part, to upstream water use.

The period 1905-1922, which was used to estimate water production allocated under the Colorado River Compact, had the highest long-term annual flow volume in the $20^{\text {th }}$ century, averaging 16.1 MAF at Lee's Ferry. The highest annual flow volume occurred in 1984 (22.2 MAF), and the highest 3 -year average is $20.3 \mathrm{MAF}$ for the period 1983-1985. The lowest annual flow volume is 3.8 MAF in 2002, followed by 3.9 MAF in 1934 and 4.8 MAF in 1977. In the Lee's Ferry record, which does not account for consumptive use upstream, flow in the early $21^{\text {st }}$ century is the lowest in more than 100 years of observations, averaging only 5.4 MAF during the 3-year period 2001-2003. The lowest previous 3-year average flows were 7.3 MAF from 1954 through 1956 and 8.0 MAF from 1933 through 1935.

Preliminary data from the U.S. Bureau of Reclamation (USBR), which include adjustments for upstream consumptive use from 1906 through 2003, indicate that the lowest 3-year average flow at Lee's Ferry, 9.4 MAF, occurred during water years 2000-2002. A water year begins on October 1 and ends on September 30 of the following calendar year. This was followed closely by water years 2001-2003 (9.5 MAF). The USBR estimated flow for water year 2004 indicates that 2002-2004 will be the lowest 3 -year average flow in the observed record at 9.2 MAF. Before the recent drought years, the lowest observed 3 year average flow reported by USBR was 9.8 MAF during the period 1953-1955.

\section{Long-Term Perspective on Drought Duration in the Colorado River Basin}

The length of observational records of climate and hydrologic conditions in the Colorado River basin is generally less than 100 years. Researchers, however, generally prefer to assess episodes like drought, which have a multiyear character, using time frames of centuries rather than decades. One way to do so is to extend the observational records of climate using proxy records; that is, to use variables that are indicative of climate, such as annual bands in coral, lake sediment deposits, and tree-ring widths, for which much longer records exist. Analyses of tree rings have been used extensively to reconstruct the history of drought in the United States for the past 800 years. Treering reconstructions of precipitation in northern Utah (Gray and others, in press) indicate that, since 1226 A.D., nine droughts have occurred lasting 15-20 years and four droughts have occurred lasting more than 20 years. Moreover, tree-ring records indicate that some past droughts in the Colorado River basin persisted for several decades (Meko and others, 1995). Such findings from the tree-ring record, coupled with new findings about the connection between the AMO and drought frequency (McCabe and others, 2004), suggest that the current drought could continue for several more years. Alternatively, the three droughts that affected the basin during the $20^{\text {th }}$ century (Fig. 3 ) each lasted from 4 to 11 years, indicating that the current dry conditions could shift to wetter conditions at any time.

\section{Selected References}

Cayan, D.R., Redmond, K.T., Riddle, L.G., 1999, ENSO and hydrologic extremes in the western United States: J. Climate 12: 2881-2893.

Diaz, H.F., and Kiladis, G.N., 1992, Atmospheric teleconnections associated with the extreme phases of the Southern Oscillation, in Diaz, H.F., and Markgraf, V.A. (eds.), El Niño: Historical and Paleoclimatic Aspects of the Southern Oscillation: Cambridge, Cambridge University Press, p. 7-28.
Enfield, D.B., Mestas-Nuñez, A.M., and Trimble, P.J., 2001, The Atlantic multidecadal oscillation and its relation to rainfall and river flows in the continental U.S.: Geophys. Res. Let. 28: 2077-2080.

Gray, S.T., Betancourt, J.L., Fastie, C.L., and Jackson, S.T., 2003. Patterns and multidecadal oscillations in drought-sensitive tree-ring records from the central and southern Rocky Mountains: Geophys. Res. Let. 30:49-1:49-4

Gray, S.T., Graumlich, L.J., Betancourt, J.L., and Pederson, G.T., 2004, A tree-ring based reconstruction of the Atlantic Multidecadal Oscillation since 1567 A.D.: Geophys. Res. Lett. 31: L12205, doi:10.1029/2004GL019932.

Gray, S.T., Jackson, S.T., and Betancourt, J.L., in press, Tree-ring based reconstructions of interannual to decadal-scale precipitation variability for northeastern Utah: J. Amer. Water Res. Assoc.

Hereford, R., Webb, R.H., and Graham, S., 2002, Precipitation history of the Colorado Plateau region, 1900-2000: U.S. Geol. Surv. Fact Sheet 119-02, 4 p.

Hidalgo, H.G., in press, Climate precursors of multidecadal drought variability in the western U.S.: Water Resources Res.

Kerr, R.A., 2000, A North Atlantic climate pacemaker for the centuries: Science, 288: 1984-1986.

LaRue, E.C., 1925, Water power and flood control of Colorado River below Green River, Utah: U.S. Geol. Surv. WaterSupply Paper 556, 176 p.

Mantua, N.J., and Hare, S.R., 2002, The Pacific decadal oscillation: J. Ocean. 58: 35-42.

McCabe, G.J., Palecki, M.A., and Betancourt, J.L, 2004, Pacific and Atlantic Ocean influences on multidecadal drought frequency in the United States: Proc. Nat. Acad. Sci. 101: 4136-4141.

Meko, D.M., Stockton, C.W., and Boggess, W.R., 1995, The tree-ring record of severe sustained drought: Water Res. Bull. 31: 789-801.

Schubert, S.D., Suzrez, M.J., Pegion, P.J., Koster, R.D., and Bacmeister, J.T., 2004, On the cause of the 1930s Dust Bowl: Science 303: 1855-1859.

Stewart, I.T., Cayan, D.R., and Dettinger, M.D., 2004, Changes in snowmelt runoff timing in western North America under a 'business as usual' climate change scenario: Clim. Change 62: 217-232.

Webb, R.H., and Betancourt, J.L., 1992, Climatic variability and flood frequency of the Santa Cruz River, Pima County, Arizona: U.S. Geol. Surv. Water-Supply Paper 2379, 40 p.

For further information, contact:

Office of the Chief Scientist for Hydrology U.S. Geological Survey 436 National Center Reston, VA 20192

(703) 648-5041 gs-w csh@usgs.gov 